\title{
Variation in Genome Size, Ploidy, Stomata, and rDNA Signals in Althea
}

\author{
Jason D. Lattier ${ }^{1}$ \\ USDA-ARS U.S. National Arboretum, Floral and Nursery Plants Research Unit, 10300 Baltimore \\ Avenue, Building 010A, Beltsville, MD 20705; Oak Ridge Institute for Science and Education, 100 \\ ORAU Way, Oak Ridge, TN 37830; and Department of Horticulture, Oregon State University, 4017 \\ Agriculture and Life Sciences Building, Corvallis, OR 97331 \\ Hsuan Chen and Ryan N. Contreras
Department of Horticulture, Oregon State University, 4017 Agriculture and Life Sciences Building,
Corvallis, OR 97331
}

Additional Index words. cytology, flow cytometry, fluorescent in situ hybridization, Hibiscus syriacus, holoploid 2C genome size, ploidy series, spindle-fiber inhibitors, stomata, 5S rDNA, 45S rDNA

\begin{abstract}
Althea (Hibiscus syriacus) is a shrub prized for its winterhardiness and colorful summer flowers. Altheas are tetraploids $(2 n=4 x=80)$; however, breeders have developed hexaploids and octoploids. Previous studies report anatomical variation among polyploids, including stomata size. The purpose of this study was 4-fold. First, identify genome size and ploidy variation in cultivars via flow cytometry and chromosome counts. Second, create a ploidy series consisting of $4 x, 5 x, 6 x$, and $8 x$ cytotypes. Third, investigate the ploidy series for variation in stomatal guard cell lengths, stomatal density, and copy number of fluorescent ribosomal DNA (rDNA) signals. Fourth, investigate segregation patterns of rDNA signals in a subset of pentaploid seedlings. Flow cytometry revealed most cultivars to be tetraploid with holoploid $2 \mathrm{C}$ genome sizes from $4.55 \pm 0.02$ to $4.78 \pm 0.06 \mathrm{pg}$. Five taxa ('Aphrodite', 'Pink Giant', 'Minerva', Azurri Satin ${ }^{\circledR}$, and Raspberry Smoothie ${ }^{\mathrm{TM}}$ ) were hexaploids (6.68 \pm 0.13 to $7.05 \pm 0.18$ pg). Peppermint Smoothie $^{\mathrm{TM}}$ was a cytochimera with tetraploid cells $(4.61 \pm 0.06 \mathrm{pg})$ and octoploid cells $(8.98 \pm 0.13 \mathrm{pg})$. To create pentaploids, reciprocal combinations were made between hexaploid 'Pink Giant' and tetraploid cultivars. To create octoploids, seedlings were treated with agar solutions containing $0.2 \%$ colchicine or $125 \mu M$ oryzalin. Guard cell lengths were significantly different among the four cytotypes: $4 x(27.36 \pm 0.04 \mu \mathrm{m}), 5 x(30.35 \pm 1.28 \mu \mathrm{m}), 6 x(35.59 \pm$ $0.63 \mu \mathrm{m})$, and $8 x(40.48 \pm 1.05 \mu \mathrm{m})$. Measurements of stomatal density revealed a precipitous decline in average density from the $4 x$ cytotype $\left(398.22 \pm 15.43\right.$ stomata $\left./ \mathrm{mm}^{2}\right)$ to $5 x$ cytotype $\left(194.06 \pm 38.69 \mathrm{stomata} / \mathrm{mm}^{2}\right) \mathrm{but}$ no significant difference among $5 x, 6 x$, and $8 x$ cytotypes. Fluorescent in situ hybridization (FISH) revealed an increase in 5S and 45S rDNA signals that scaled with ploidy: $4 x$ (two 5S + four 45S), $6 x$ (three 5S + six 45S), and 8x (four 5S + eight 45S). However, pentaploid (5x) seedlings exhibited random segregation of rDNA signals between the $4 x$ and $6 x$ cytotypes, including all six possible combinations (two 5S, three 5S) $\times$ (four 45S, five 45S, six 45S).
\end{abstract}

Hibiscus is a genus in the Malvaceae comprising $\approx 250$ species of mostly tropical and subtropical trees, shrubs, and herbs divided into 10 sections (Fryxell, 1988; Van Laere et al., 2007). However, few species extend their natural range into temperate climates. Rose of sharon or althea has been a staple ornamental shrub in American gardens and other temperate regions, prized for its winterhardiness, range of flower colors, and unique flower traits, including single-flowered, doubleflowered, and semidouble types (Contreras and Lattier, 2014).

The basic chromosome number of Hibiscus syriacus has been reported as $x=20$, with most being tetraploid, $2 n=4 x=80$ (Skovsted, 1941). However, confusion persists as some reports claim H. syriacus to be a natural diploid. Van Laere et al. (2007) addressed this discrepancy confirming that "diploid" often is used instead of the correct term "tetraploid." This has led to confusion in classifying hexaploid cultivars (so-called triploids) and octoploid cultivars (so-called tetraploids). A recent draft genome revealed high copy numbers in numerous genes compared with closely related diploid species, confirming $H$.

Received for publication 17 Dec. 2018. Accepted for publication 19 Feb. 2019. This study was funded by the Oregon Department of Agriculture and Oregon State University.

${ }^{1}$ Corresponding author. E-mail: jdlattier@gmail.com. syriacus as a tetraploid (Kim et al., 2017). Although the majority of taxa investigated have been tetraploid, higher ploidy levels have been reported including hexaploids ('Aphrodite', 'Diana', 'Helene', 'Minerva', 'Melrose', 'Pink Giant', and 'Shimsan') and octoploids ('Purple CV', 'Purple $\mathrm{CV}_{2}$ ', 'Red Heart CV', ' $\mathrm{Sp}_{1}$ ', $\mathrm{Sp}_{2}$ ', and ' $\mathrm{Sd}_{1}$ ') (Eeckhaut et al., 2004; Egolf, 1970, 1981, 1986, 1988; Lee and Kim, 1976; Shim et al., 1993; Van Huylenbroeck et al., 2000; Van Laere et al., 2006, 2007, 2009).

Spindle-fiber inhibitors (SFIs) have been used to double chromosomes in Hibiscus. Contreras et al. (2009) treated meristems of seedlings with an agar solution containing oryzalin to induce autoallooctoploids of Hibiscus acetosella. Li and Ruter (2017) soaked seedlings in colchicine and oryzalin solutions to induce autopolyploids in Hibiscus moscheutos. Hexaploids 'Aphrodite', 'Diana', 'Minerva', and 'Helene' of H. syriacus were created at the U.S. National Arboretum by crossing improved selections with colchicine-treated seedlings of 'William R. Smith'. Ploidy of the hexaploids 'Melrose' and 'Pink Giant' remained unreported before a flow cytometry survey by Van Huylenbroeck et al. (2000). Researchers in Korea used SFIs and cross-pollination to create hexaploid 'Shimsan' and octoploids 'Purple CV', 'Purple $\mathrm{CV}_{2}$ ', 'Red Heart CV', 'Sp ${ }_{1}$, ' $\mathrm{Sp}_{2}$ ', and ' $\mathrm{Sd}_{1}$ ' (Lee and Kim, 1976; Shim et al., 1993). Van 
Laere et al. (2006) created hexaploid lines of blue-flowered $H$. syriacus derived from colchicine-treated seedlings of 'Blue Bird' and 'Woodbridge'. Although colchicine has proven effective, no study exists demonstrating the effectiveness of oryzalin in chromosome doubling of $H$. syriacus.

Ploidy levels and chromosome numbers in Hibiscus have been confirmed in previous studies using combinations of flow cytometry and root squashes (Contreras et al., 2009; Shim et al., 1993; Van Huylenbroeck et al., 2000; Van Laere et al., 2006, 2009). In addition, anatomical differences among polyploids have been investigated. Observations of morphological characters have consistently shown "gigas" effects among polyploids, including larger flowers, increased flowering duration, and reduced seed production (Egolf, 1970, 1981; Van Huylenbroeck et al., 2000). In $H$. acetocella, Contreras et al. (2009) recorded differences in plant height, leaf size, internode length, canopy volume, pollen diameter, and guard cell lengths among polyploids. In H. syriacus, Lee and Kim (1976) recorded differences in leaf thickness, length of guard cells, diameter of pollen grains, and wood fiber anatomy. Shim et al. (1993) reported differences in leaf width, leaf length, flower size, eyespot size, pollen spine number, and pollen exine apertures across ploidy in H. syriacus. Van Laere et al. (2009) investigated pollen diameter differences and triad formation among polyploids of $H$. syriacus. Polyploidy also has been hypothesized to effect abiotic stress responses in woody plants, with few studies on drought stress (Li et al., 2009; Pustovoitova et al., 1996) and no current studies on coldtolerance.

Not all morphological characters are effective at determining genome size and ploidy changes in plants. One reliable character is stomatal guard cell size and density. Genome size has been shown to have a positive correlation with stomata size and a negative correlation with stomata density across a wide range of angiosperms (Beaulieu et al., 2008). Stomata have proven useful anatomical characters to differentiate ploidy levels in woody plant species (Joly and Bruneau, 2007; McGoey et al., 2014; Padoan et al., 2013). Stomatal guard cells have proven a robust enough character that they have been useful for predicting ploidy in dried herbarium specimens (Buechler, 2000; Chen et al., 2009; Saltonstall et al., 2007), and even fossilized leaves (Buechler, 2000). Stomata measurements and anatomical descriptions have been reported for many species of Hibiscus (Contreras et al., 2009; Essiett and Iwok, 2014; Li and Ruter, 2017; Zhuang and Song, 2005), yet only one study has reported an association between ploidy and stomata variation in H. syriacus (Lee and Kim, 1976). Guard cell lengths of tetraploid controls ranged from 28 to $29 \mu \mathrm{m}$, whereas those of colchicine-induced octoploids (' $\mathrm{Sp}_{1}$ ', ' $\mathrm{Sp}_{2}$ ', and ' $\mathrm{Sd}_{1}$ ') ranged from 32 to $42 \mu \mathrm{m}$. However, there are no confirming studies and no data on interploid cytotypes, such as pentaploids or hexaploids.

Confirming ploidy level in woody plants can be achieved with flow cytometry and traditional cytology, such as root squashes. Root squashes can be difficult and tedious as many woody plants possess small, friable roots with numerous, small chromosomes (Lattier et al., 2013; Ochatt, 2008). Fluorescent labeling of rDNA could be used to confirm ploidy levels in a ploidy series with numerous, small chromosomes, as well as provide a tool for investigating chromosome segregation through copy number variation in rDNA signals of interploid hybrids.

rDNA has been used to study the origin and evolution of plant genomes in ancient allopolyploids (Volkov et al., 2017) as well as artificial autopolyploids (Gomes et al., 2014) and interploid hybrids (Wang et al., 2015a). Tandem repeated rDNA units are highly conserved throughout all plants and often are combined with more variable, rapidly evolving intergeneric spacer regions (Volkov et al., 2017). Frequently used loci include the 5S and 45S (Ribeiro et al., 2008; Volkov et al., 2017). The 45S and 5S rDNA loci are usually located at different sites on different chromosomes, and their transcription is carried out by different RNA polymerases (Srivastava and Schlessinger, 1991). These markers have become widely used in FISH, a technique that fluorescently labels rDNA and allows for comparison of copy number and location. FISH has proven an efficient technique for cytological studies in woody angiosperms where karyotyping is limited due to the small size of chromosomes (Anamthawat-Jónsson, 2003; Prado et al., 1996). No data exist on rDNA signals in Hibiscus.

The objectives of this study were 1) to identify genome size and ploidy variation in cultivars of $H$. syriacus; 2) to create a ploidy series consisting of $4 x, 5 x, 6 x$, and $8 x$ cytotypes using a combination of interploid hybridization and autopolyploid induction via colchicine and oryzalin; 3) to investigate the ploidy series for variation in stomatal guard cell length, stomatal density, and copy number of fluorescent rDNA signals; and 4) to investigate segregation patterns in rDNA signals in a subset of pentaploid seedlings.

\section{Methods and Materials}

Plant material. Plants of $H$. syriacus were collected from nurseries, gardens, and arboreta to represent a cross section of available cultivars in the nursery trade (Table 1). Plants were maintained in containers at the Lewis Brown Farm at Oregon State University (Corvallis). Original cultivar and trademark names were maintained from each source (Table 1); however, usually one name becomes common in the nursery trade as the market name. For simplicity, only market names (cultivar or trademark) will be used hereafter.

Flow CyTOMETRy. Holoploid (2C) relative genome sizes were recorded for each accession. For each plant, three expanded leaves were collected randomly to represent three samples of nuclei for each accession. A single leaf was sampled from additional clones of each taxon. If genome size variability was found among additional "clones," then three leaves were screened and additional genome sizes were reported for those accessions, as in $H$. syriacus 'Aphrodite' (Table 1). For each leaf sample, an internal standard of known genome size was included [Solanum lycopersicum 'Stupicke' $(2 \mathrm{C}=1.96 \mathrm{pg})]$. Combined leaf tissues $\left(1-2 \mathrm{~cm}^{2}\right)$ representing a sample plus internal standard were co-chopped in $400 \mu \mathrm{L}$ of a buffer solution (Cystain Ultraviolet Precise P Nuclei Extraction Buffer; Sysmex, Görlitz, Germany). The resulting solution was poured through a $30-\mu \mathrm{m}$ gauze filter (Celltrics; Partec, Münster, Germany) into a 3.5-mL plastic tube (Sarstedt Ag \& Co., Nümbrecht, Germany) followed by $1.6 \mathrm{~mL}$ of fluorochrome stain [4',6-diamidino-2-phenylindole (DAPI); Cystain Ultraviolet Precise P Staining Buffer; Partec]. The nuclei suspension was analyzed using a flow cytometer (CyFlow Ploidy Analyzer; Partec) with a minimum of 3000 nuclei analyzed per sample at a cV for each histogram less than 10. References to genome size and ploidy follow the terminology proposed by Greilhuber et al. (2005). Holoploid (2C) genome size was calculated as: 
Table 1. Ploidy and relative holoploid 2C genome size in cultivars of Hibiscus syriacus.

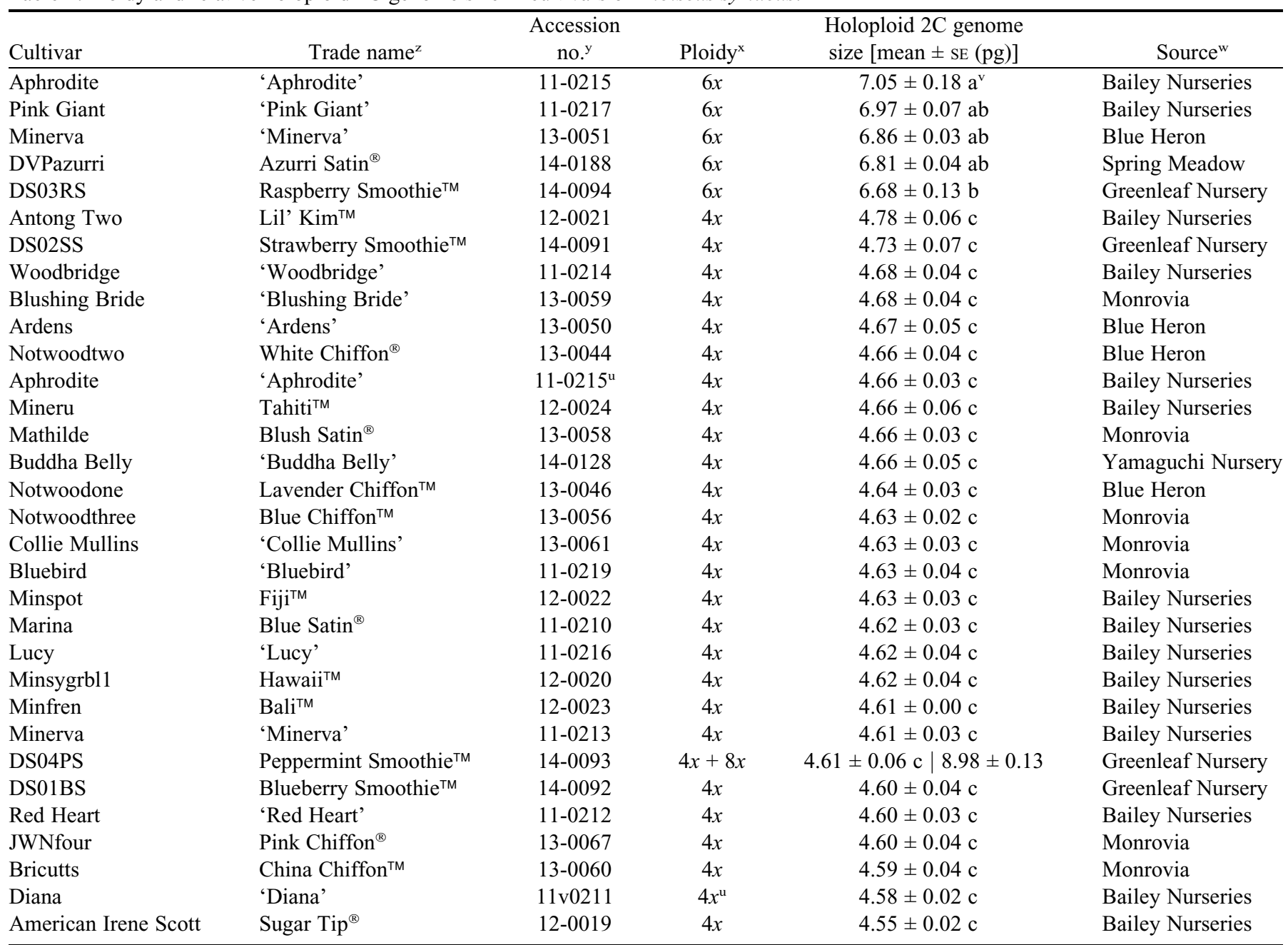

${ }_{\mathrm{z} \text { Most common name in nursery trade. }}$

${ }^{\mathrm{y}}$ Accession number in the Ornamental Plant Breeding Laboratory at Oregon State University (Corvallis). Multiple replicates from the same source under the same accession number.

${ }^{\mathrm{x}}$ Ploidy level inferred from genome size estimate.

${ }^{\mathrm{w}}$ Container plant collected from the following sources: Bailey Nurseries (Yamhill, OR), Blue Heron Farm (Corvallis, OR), Greenleaf Nursery (Park Hill, OK), Monrovia (Dayton, OR), Spring Meadow Nursery (Grand Haven, MI), Yamaguchi Plantsman Nursery (Gifu, Japan).

${ }^{\vee}$ Minimum significant difference of 0.31 based on Tukey's honestly significant difference test.

${ }^{\mathrm{u}}$ Chromosomes counted using root tip cytology.

$$
\begin{aligned}
2 C= & \text { DNA content of standard } \\
& \times \frac{\text { mean fluorescence value of sample }}{\text { mean fluorescence value of standard }} .
\end{aligned}
$$

Cyтology. To calibrate genome sizes from flow cytometry with ploidy levels, a root squash was performed on a tetraploid cytotype following the protocol of Lattier et al. (2017). Metaphase chromosomes were screened at magnification $\times 200$ using a compound light microscope (Axio Imager A1; Zeiss, Oberkochen, Germany). Fifteen highly resolved cells were imaged under oil immersion at a magnification of $\times 1000$. Chromosomes were imaged at different focal distances and focusstacked using the Auto Blend utility in Photoshop CC 2015.5.1 (Adobe Systems, San Jose, CA). Greater ploidy levels (5x, 6x, and $8 x$ ) were confirmed using root squashes combined with rDNA signal variation from FISH analysis (details to follow).
Ploidy SERIEs. From 2013 to 2015, interploid hybridization and induced autopolyploidy were used to create a ploidy series $(4 x, 5 x, 6 x$, and $8 x)$. Interploid hybridizations were performed between a hexaploid taxon, 'Pink Giant', and a suite of tetraploid cultivars. A total of 935 crosses were performed with 'Pink Giant'. When using 'Pink Giant' as a seed parent, 379 crosses were attempted representing 19 different combinations. When using 'Pink Giant' as a pollen parent, 556 crosses were attempted representing 24 different combinations. Controlled crosses were performed during summer in a glasshouse kept free of pollinators with day/night set temperatures of $25 / 20{ }^{\circ} \mathrm{C}$ and a $16-\mathrm{h}$ photoperiod. Dried capsules were collected before dehiscence in fall. Seed from each cross were directly sown into 1.3-L containers filled with a peat-based medium (Metro-Mix; Sun Gro Horticulture, Agawam, MA) and seeds were evenly spaced at 30 or fewer seeds per pot. Seedlings from each successful cross were screened using flow cytometry. A vigorous selection with an 
intermediate, pentaploid genome was selected for the ploidy series, H2013-078-01 ('Pink Giant' $\times$ Bali'TM).

To create octoploid cytotypes, germinating seedling meristems were treated with SFIs at different concentrations and durations. Open-pollinated (OP) seeds were collected from 'Aphrodite' and Bali ${ }^{\mathrm{TM}}$ and sown into 1.3-L containers filled with peat-based medium (Metro-Mix). Replicates of five pots with subsamples of 15 seeds per pot were used for each treatment. Pots were grown under cool-white fluorescent lights at $90 \mathrm{mmol} \cdot \mathrm{m}^{-2} \cdot \mathrm{s}^{-1}$ at 22 to $25^{\circ} \mathrm{C}$ with a $16-\mathrm{h}$ photoperiod.

As seedlings germinated, they were treated with two SFIs [oryzalin (Surflan AS; United Phosphorous, King of Prussia, PA) and colchicine (Sigma-Aldrich, St. Louis, MO)] in four treatment combinations: $125 \mu \mathrm{M}$ oryzalin for $5 \mathrm{~d}, 125 \mu \mathrm{M}$ oryzalin for $10 \mathrm{~d}, 125 \mu \mathrm{M}$ oryzalin for $20 \mathrm{~d}$, and $0.2 \%$ colchicine for $10 \mathrm{~d}$. Colchicine at $0.2 \%$ was previously reported effective (Van Laere et al., 2006), yet efficacy of oryzalin has not been reported for $H$. syriacus. In addition, a negative control was included (SFI-free agar droplet for $10 \mathrm{~d}$ ). Droplets were applied daily after cotyledons expanded to provide access to the apical meristem. Containers were covered with clear humidity domes to maintain treatment droplets. Containers were held in non-draining plastic trays and seedlings were subirrigated as needed. To improve cellular penetration, 1\% (v/v) dimethyl sulfoxide (Sigma-Aldrich) was added to the colchicine treatment. To congeal all treatments and maintain droplets on the meristems over the course of each day, $0.55 \%$ agar $(\mathrm{w} / \mathrm{v})$ (Sigma-Aldrich) was added to each treatment.

After treatments, 13 germinated seedlings from each container were transplanted into individual $0.95-\mathrm{L}$ containers and randomized on a glasshouse bench. As plants grew, necrosis at the treatment sites necessitated immediate cutting propagation. Single and two-node cuttings were taken from many seedlings. Due to the slow recovery post rooting, leaf samples could not be collected for flow cytometry. Therefore, several developing roots were collected from a subset of treatment plants and a single sample was analyzed for each via flow cytometry to identify putative octoploids. A vigorous selection (OP2014-19) with an octoploid genome size resulting from the $125-\mu \mathrm{M}$ oryzalin 5 -d treatment was selected for the ploidy series. The following year, young expanded leaves were analyzed via flow cytometry to confirm the ploidy level of this selection. The final ploidy series comprised four accessions: Bali ${ }^{\mathrm{TM}}(4 x)$, H2013078-01 'Pink Giant' $\times$ Bali $^{\mathrm{TM}}(5 x)$, 'Pink Giant' $(6 x)$, and OP2014-19 oryzalin-treated OP Bali ${ }^{\mathrm{TM}}$ seedling $(8 x)$.

Stomata measurements. In Summer 2016, four clonal plants representing the ploidy series were growing in the same environment at the Lewis Brown Farm. Three mature leaves for each plant were selected from random branches. Similar-sized leaves were selected about three to four nodes basipetal to the developing meristem. For each leaf, an area between the midrib and first primary vein on the abaxial leaf surface was treated with a thin coat of clear, nitro-cellulose fingernail polish. Strips of clear packing tape were applied to the nail polish. After nail polish dried, the tape strips were removed carefully with forceps. The resulting cuticle peels containing relief impressions of stomata were mounted to microscope slides. Each slide represented a random leaf sample and was treated as a replicate for further analysis. Each slide was viewed with a compound light microscope (Axio Imager A1) at a magnification of $\times 200$.

Images were captured randomly across the microscope slides (AxioCam 105 Color; Zeiss) and processed using image analysis software (AxioVision; Zeiss). Five to 10 images totaling 97 to 289 stomata per slide were used to measure stomatal guard cell length for each cytotype. Total stomata measured (2281) for each cytotype were 799 (tetraploid), 433 (pentaploid), 524 (hexaploid), and 525 (octoploid). All stomata were measured using the line measurement tool (AxioVision). Stomata per slide were treated as subsamples and stomatal guard cell lengths were averaged for each slide. Average guard cell lengths per slide were averaged for a total of three reps per cytotype. For stomatal density, 50 randomly captured images per slide were analyzed for a total of 150 images per cytotype. Total stomata counted $(21,015)$ for each cytotype were 9029 (tetraploid), 4400 (pentaploid), 4095 (hexaploid), and 3491 (octoploid). The number of stomata was counted in each image and an average stomata number per slide was calculated. Average stomata counts for each slide were averaged for a total of three reps per cytotype. To report stomatal density (stomata per square millimeter), each stomata count was multiplied by 6.62 to scale up from the frame of view at a magnification of $\times 200(449.2 \mu \mathrm{m} \times$ $336.5 \mu \mathrm{m})$ per the following formula:

$$
\begin{aligned}
& \text { Stomatal density (stomata per square millimeter) } \\
& \quad=\text { stomata count } \times \frac{1}{(449.2 \mu m \times 336.5 \mu m) \times 1 e^{-6}}
\end{aligned}
$$

After guard cell lengths and stomatal densities were calculated, stomatal index was calculated according to $\mathrm{Li}$ et al. (1996):

$$
\begin{aligned}
& \text { Stomatal index }=\text { stomata length }(\text { micrometers }) \\
& \times \text { stomata density }(\text { stomata per square millimeter })
\end{aligned}
$$

Photomicrographs of cuticle peels from each cytotype were produced from layered images composed of multiple focal distances viewed at a magnification of $\times 630$. Images were layered using the Auto Blend feature in Photoshop. Average stomata estimates (as well as ploidy levels) were subjected to analysis of variance and means were separated using Fisher's least significant difference $[\alpha<0.05$ (SAS Studio; SAS Institute, Cary, NC)].

FISH. Synthesis of probes for FISH was carried out per Chang et al. (2009). A plasmid DNA construct from Triticum aestivum, pTA794 (Gerlach and Dyer, 1980), containing the 5S rDNA repeat (410 bp) was labeled with digoxigenin (DIG-11dUTP) by nick translation (Roche Diagnostics, Mannheim, Germany). The digoxigenated probe was detected using Texas red (antidigoxigenin-rhodamine Fab fragments) (14877500; Roche Diagnostics). Another plasmid DNA from T. aestivum, $\mathrm{p}$ TA71 (Gerlach and Bedbrook, 1979), containing $\approx 9 \mathrm{~kb}$ of coding sequences from the 45S rRNA gene was labeled with biotin (Biotin-16-dUTP) by nick translation (Roche Diagnostics). The biotinylated probe was detected using fluorescein antibiotin (SP-3040; Vector Laboratories, Burlingame, CA). Counterstaining was performed with DAPI suspended in a mounting medium at $1.5 \mu \mathrm{g} \cdot \mathrm{mL}^{-1}$ (Vectashield; Vector Laboratories).

Roots tips for FISH were collected from softwood cuttings of tetraploid Bali ${ }^{\mathrm{TM}}$, hexaploid 'Pink Giant', octoploid OP201419 , and a random sample of putative pentaploids from interploid crosses. Root tip pre-fixative, fixative, and enzyme digestion steps follow the protocol of Lattier et al. (2017). After digestion, the enzyme solution was wicked away using 
low-lint tissue (VWR International, Radnor, PA) and roots were squashed. Dried slides were treated for $15 \mathrm{~min}$ in diluted Giemsa stain (Sigma-Aldrich) and were screened for condensed chromosomes at a magnification of $\times 200$ on a light microscope (Axio Imager A1). Slides with condensed chromosomes were selected for FISH. Preparation for FISH analysis was carried out per previous methods (Chen et al., 2015; Chung et al., 2008). Prepared slides were viewed in the dark on a compound microscope (Axio Imager A1) with a fluorescent light source (X-Cite 120Q; Excelitas Technologies, Waltham, MA). At least five metaphase cells with clear rDNA signals were observed for each taxon. Images of fluorescent DAPI, 5S, and $45 \mathrm{~S}$ signals were captured separately (AxioCam MRm; Zeiss) and images were combined using image analysis software (AxioVision).

\section{Results and Discussion}

Flow Cytometry. Significant differences were found among the taxa investigated for holoploid $2 \mathrm{C}$ genome size $(P<0.01)$. Most taxa investigated were tetraploid with genome sizes ranging between $4.55 \pm 0.02 \mathrm{pg}$ in Sugar Tip ${ }^{\circledR}$ to $4.78 \pm$ $0.06 \mathrm{pg}$ in Lil' $\mathrm{Kim}^{\mathrm{TM}}$ (Table 1). No statistical difference in genome size was found among the tetraploid cultivars (Table 1). Ploidy and chromosome numbers were confirmed for the tetraploid group by root tip counts of 'Diana' $(4.58 \pm 0.02 \mathrm{pg})$ at $2 n=4 x=80$ (Fig. 1), in contrast to previous reports of 'Diana' being a hexaploid (Egolf, 1970; Shim et al., 1993; Van Huylenbroeck et al., 2000). Other putative hexaploids from the U.S. National Arboretum were found to be tetraploid in contrast to former reports of hexaploidy (Egolf, 1986, 1988), including a single accession of 'Minerva' (4.61 $\pm 0.03 \mathrm{pg})$ and a single accession of 'Aphrodite' (4.66 $\pm 0.03 \mathrm{pg})$ (Table 1).

Five accessions were found to have genome sizes significantly larger than the tetraploid taxa (Table 1). 'Aphrodite', 'Minerva', and all accessions of 'Pink Giant', Azurri Satin ${ }^{\circledR}$, and Raspberry Smoothie ${ }^{\mathrm{TM}}$ proved to be hexaploids (Table 1). Holoploid genome sizes ranged from $6.68 \pm 0.13 \mathrm{pg}$ in Raspberry Smoothie ${ }^{\mathrm{TM}}$ to $7.05 \pm 0.18 \mathrm{pg}$ in 'Aphrodite'. Having two cytotypes of 'Aphrodite' and 'Minerva' in the cultivar collection could represent a reversion to the tetraploid state over many years of propagation. However, nursery practices, including sexual propagation of cultivars, cultivar substitution, mislabeling, and seedling invasion of stock plants, have been shown to degrade cultivar collections in previous studies (Fantz, 1994). Confirming a previous report by Van Huylenbroeck et al. (2000), 'Pink Giant' was found to be a hexaploid at $6.97 \pm 0.07 \mathrm{pg}$ (Table 1). Flower color and form were similar for hexaploids 'Aphrodite', 'Pink Giant', and 'Minerva' (single, pink flowers). However, Azurri Satin ${ }^{\circledR}$ represents the first single, blueflowered hexaploid $H$. syriacus, produced by Van Laere et al. (2006). Notably, with the inclusion of the pink, double-flowered Raspberry Smoothie ${ }^{\mathrm{TM}}$, we report for the first time a hexaploid, double-flowered H. syriacus. Depending on their fertility, Azurri Satin $^{\circledR}$ and Raspberry Smoothie ${ }^{\mathrm{TM}}$ may offer new opportunities to breeders seeking sterile hybrids with novel floral phenotypes via interploid hybridization.

In addition to tetraploid and hexaploid cytotypes, one accession, Peppermint Smoothie ${ }^{T M}$, was found to be a cytochimera, with both tetraploid cells $(4.61 \pm 0.06 \mathrm{pg})$ and octoploid cells $(8.98 \pm 0.13 \mathrm{pg})$ and represents the only mixoploid currently reported (Table 1). If the LII histogenic layer is

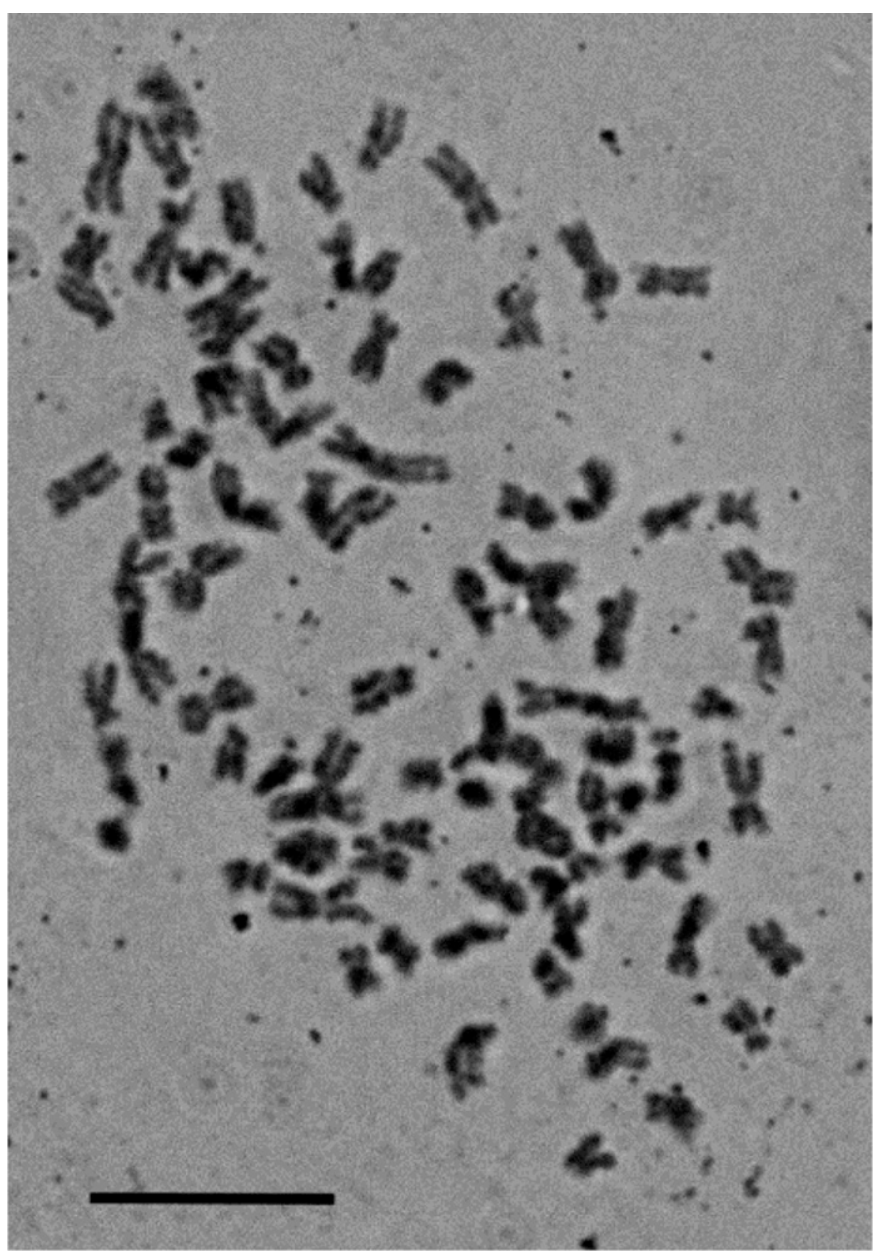

Fig. 1. Photomicrograph of metaphase chromosomes from root tip cells of Hibiscus syriacus 'Diana' $(2 n=4 x=80)$ viewed at $\times 1000$; scale bar $=10 \mu \mathrm{m}$.

octoploid, this cultivar may prove useful for creating novel hexaploids for further breeding.

Ploidy Series. After 935 reciprocal crosses between tetraploid cultivars and 'Pink Giant', 112 capsules were recovered containing a total of 564 seeds. Viable seedlings were recovered from 16 combinations and 'Pink Giant' proved successful as both a seed parent and pollen parent. A subset of these combinations was evaluated with flow cytometry, which revealed numerous seedlings with intermediate (putative pentaploid) genome sizes (Fig. 2). Only one cross, 'Woodbridge' $\times$ 'Pink Giant', yielded a near-tetraploid average genome size (4.94 \pm 0.19 pg) (Fig. 2) likely due self-pollination. However, one seedling (H2012-041-01), resulting from this cross had a hexaploid genome size of $6.78 \mathrm{pg}$ in a single estimate from flow cytometry. Another cross, $H$. syriacus Bali $^{\mathrm{TM}} \times$ 'Pink Giant' consistently gave pentaploid genome sizes. Four full-sib seedlings were tested using flow cytometry, yielding an average genome size of $5.70 \pm 0.04$ (Fig. 2). One vigorous seedling (H2013-078-01), representing this cross was selected for the ploidy series. This seedling had an intermediate genome size $(5.55 \mathrm{pg})$ between its two parents and was included as a representative pentaploid in further analysis of stomata anatomy and copy number variation of rDNA signals.

During the octoploid induction experiment, treatments with SFIs appeared to leave the meristem undamaged and intact 


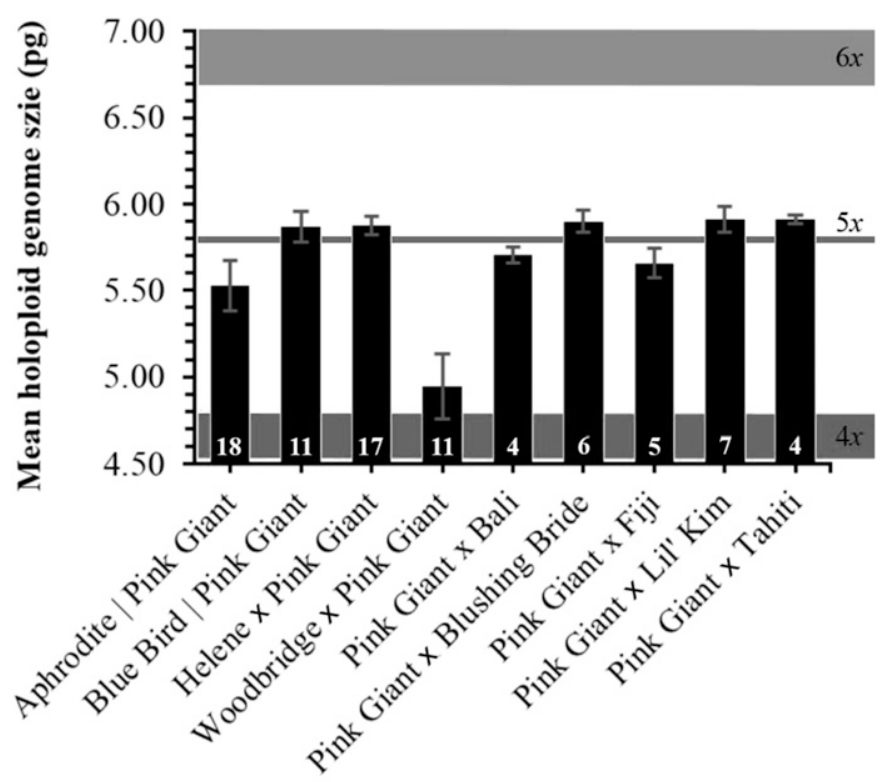

Interploid $(4 x \mid 6 x)$ combinations

Fig. 2. Flow cytometry estimates of average holoploid $2 \mathrm{C}$ genome sizes in a subset interploid crosses between tetraploid Hibiscus syriacus cultivars and hexaploid H. syriacus 'Pink Giant'. Reciprocal combinations indicated by "|" symbol, whereas " $\mathrm{x}$ " represents a unidirectional cross. Vertical bars represent mean \pm SE for each cross. White letters within vertical bars represent the number of seedlings measured for each cross. Horizontal $4 x$ bar represents the range of tetraploid genome sizes found among cultivars of $H$. syriacus. Horizontal $6 x$ bar represents the range of hexaploid genome sizes found among cultivars of $H$. syriacus. Horizontal $5 x$ line represents the theoretical pentaploid genome size based on an average of $4 x$ and $6 x$ genome sizes.

during germination and subsequent flushes of new growth. However, several weeks after potting, necrosis began to appear on nearly all seedlings. Plants produced healthy shoots posttreatment only to later spontaneously abscise at the treatment site. Control plants appeared unaffected, indicating that treatment with SFIs to young seedlings caused the tissue death near the treatment site. Subsequent cuttings were taken acropetal to the treatment site and rooted under mist. Thirty-four plants were recovered from the autopolyploid induction experiment, representing a fraction of the original seedling population. Before potting the cuttings, adventitious roots were collected for analysis via flow cytometry. Adventitious roots provided only enough material for a single run on the flow cytometer per sample without proving too damaging to the young cuttings. Samples represented the L-III histogenic layer from which adventitious roots are derived.

Of the remaining plants, only two 'Aphrodite' OP seedlings treated with colchicine produced shoots that rooted. Flow cytometry of roots revealed seedlings OP2014-27 and OP2014-35 had genome sizes of $8.37 \mathrm{pg}(8 x)$ and $12.22 \mathrm{pg}$ $(\approx 10 x)$, respectively. No colchicine-treated seedlings of Bali ${ }^{\mathrm{TM}}$ remained for genome size analysis. Two 10-d and 20-d oryzalin treatments of 'Aphrodite' OP seedlings were recovered for flow cytometry analysis of roots, which had genome sizes consistent with tetraploids. The remaining 30 accessions were all recovered from 5 -d oryzalin treatments, with 18 representing 'Aphrodite' OP seedlings and 12 representing Bali ${ }^{\text {TM }}$ OP seedlings. At least one representative from each of the original five replicates was recovered for flow cytometry analysis of roots. For the 'Aphrodite' OP seedlings, 13 seedlings (72\%) were found to be octoploid with an average genome size of 8.36 \pm 0.11 pg. For the Bali ${ }^{\mathrm{TM}}$ OP seedlings, 11 seedlings $(92 \%)$ were found to be octoploids with an average genome size of $8.36 \pm$ $0.22 \mathrm{pg}$. Although few seedlings were recovered from the original experiment and only one sample per seedling was analyzed using flow cytometry, our results indicate that colchicine and oryzalin provide an effective way to produce octoploids.

From this autopolyploid population, one Bali ${ }^{\mathrm{TM}}$ OP seedling (OP2014-19) from the 5-d oryzalin treatment was selected for further flow cytometry analysis on leaf tissue, yielding an average genome size of $8.88 \pm 0.01 \mathrm{pg}$. This seedling was selected as a representative ocotoploid for the ploidy series and for further analysis of stomata anatomy and variation in rDNA signals.

As expected, holoploid genome sizes from leaf nuclei were different among the four taxa $[4 x, 5 x, 6 x, 8 x$ $(P<0.01)]$. Cell size, including stomata, increased with increasing ploidy (Fig. 3). Guard cell diameter was significantly different among the four taxa in the ploidy series $(P<0.01)$ and ranged from $27.36 \pm$ $0.04 \mu \mathrm{m}$ in the tetraploid to $40.48 \pm$ $1.05 \mu \mathrm{m}$ in the octoploid. These results confirm previous reports that stomata size could be useful in distinguishing ploidy in different species of Hibiscus (Contreras et al., 2009; Zhuang and Song, 2005). In contrast to stomata in $H$. syriacus, stomata guard cell lengths reported in Hibiscus schizopetalus, Hibiscus mutabilis, and Hibiscus rosa-sinensis were much smaller, ranging from $14.26 \pm 0.39 \mu \mathrm{m}$ to

Fig. 3. Stomata length and density in a ploidy series in Hibiscus syriacus. Photomicrographs above bar graph are representative cuticle peels for each ploidy level viewed at $\times 630$ magnification (scale bar $=10 \mu \mathrm{m}$ ). Ploidy series included tetraploid $H$. syriacus Bali ${ }^{\mathrm{TM}}$ (12-0023), pentaploid hybrid $H$. syriacus 'Pink Giant' $\times$ Bali $^{\text {TM }}(\mathrm{H} 2013-$ 078-01), hexaploid H. syriacus 'Pink Giant' (11-0217), and an octoploid, oryzalin-treated, open-pollinated seedling from $H$. syriacus Bali $^{\top M}$ (OP2014-19). 
$21.10 \pm 0.65 \mu \mathrm{m}$, respectively (Zhuang and Song, 2005). Essiett and Iwok (2014) reported lengths for $H$. acetocella, H. rosasinensis, Hibiscus surattensis, and Hibiscus arnottianus similar to our measurements in $H$. syriacus. In induced autotpolyploids of $H$. acetocella 'Panama Red', guard cell size increased from $25 \mu \mathrm{m}$ in the tetraploid to $36 \mu \mathrm{m}$ in the octoploid. Our results are also comparable with a previous report on tetraploid and colchicine-induced octoploid $H$. syriacus. Lee and Kim (1976) found that average guard cell lengths of control tetraploid $H$. syriacus ranged from 28 to $29 \mu \mathrm{m}$ whereas octoploid guard cell lengths ranged from 32 to $42 \mu \mathrm{m}$. Li and Ruter (2017) observed average guard cell lengths in $H$. moscheutos ranged from $24 \mu \mathrm{m}$ for diploids to $32 \mu \mathrm{m}$ for tetraploids (J. Ruter, personal communication). These results combined with the current study indicate that guard cell length may be useful for evaluating both interploid and interspecific hybrids in Hibiscus.

Significant differences were found in stomatal density among the four taxa in the ploidy series $(P<0.01)$ and ranged from $398.22 \pm 15.43 \mathrm{stomata} / \mathrm{mm}^{2}$ in the tetraploid to $154.01 \pm$ 8.90 stomata $/ \mathrm{mm}^{2}$ in the octoploid. There was a significant, precipitous decline in stomatal density from the tetraploid to pentaploid cytotype, representing a 2-fold difference in stomata density. However, no significant differences were detected among the pentaploid, hexaploid, and octoploid cytotypes. A plot of stomatal guard cells sizes and stomatal densities illustrates the negative relationship between guard cell length and density (Fig. 3). The positive relationship between genome size and stomata size, as well as the negative relationship between genome size and stomatal density, proposed by Beaulieu et al. (2008), was observed in the H. syriacus ploidy series.

Stomatal index has proven a useful anatomical character for comparing taxa because it is independent of the environment, size, or portion of the leaf surface (Essiett and Iwok, 2014). However, measures differ depending on if total epidermal cell counts are performed, as in Essiett and Iwok (2014), vs. the method used in the current study (Li et al., 1996) that solely relies on the product of the stomata length by the stomata density. For the ploidy series in H. syriacus, significant differences were found in stomatal indices among the four taxa investigated $(P<0.01)$. Average stomatal index was $10,894.45 \pm$ 411.95 for the octoploid, $5810.05 \pm 995.15$ for the hexaploid, $6411.81 \pm 355.68$ for the pentaploid, and $6215.92 \pm 196.89$ for the tetraploid taxa. The strong effect from the change in stomatal density from tetraploid to pentaploid cytotype resulted in the same trend in the pairwise comparisons among ploidy levels. Polyploids in Betula papyrifera also were found to have smaller stomatal indices compared with the diploid controls ( $\mathrm{Li}$ et al., 1996). Therefore, the reduction in stomatal index in $H$. syriacus at greater ploidy levels may lead to an increase in stress tolerance by reduced transpiration. This effect has been claimed in woody plants but has been illustrated only in herbaceous taxa such as the drought-tolerant autopolyploids in Arabidopsis thaliana (Del Pozo and Ramirez-Parra, 2014) and drought-tolerant allopolyploids in Triticum (Xiong et al., 2006). The ploidy series of Hibiscus syriacus may prove useful in future research on physiological differences across ploidy in woody plants.

FISH. The number of signals from the 5S rDNA locus varied from two (in the tetraploid) to four (in the octoploid), whereas signals from the $45 \mathrm{~S}$ rDNA locus varied from four (in
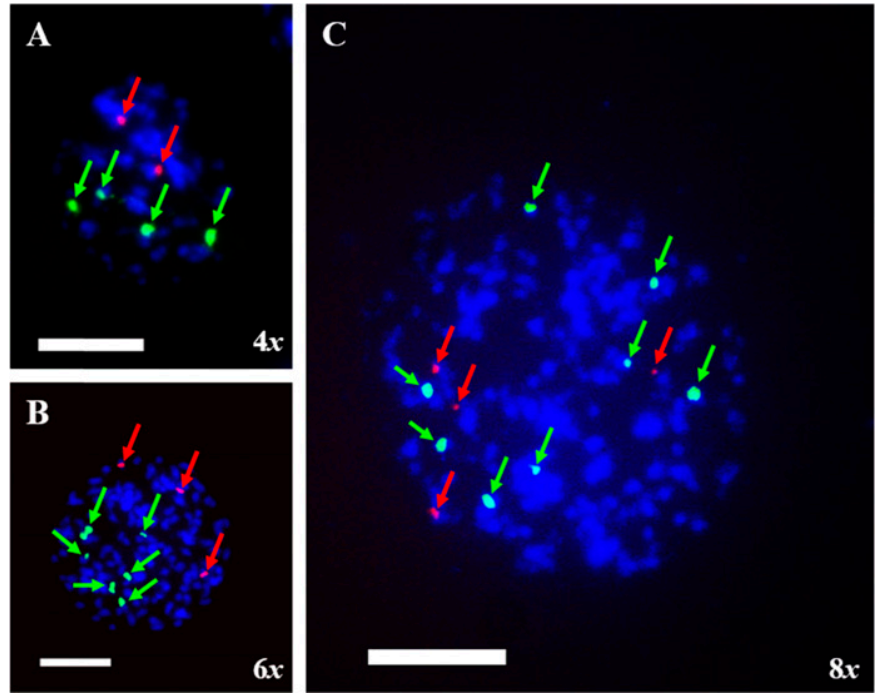

Fig. 4. Fluorescent in situ hybridization (FISH) analysis of metaphase, root tip chromosomes in a ploidy series of Hibiscus syriacus. Chromosomes displaying variation in $5 \mathrm{~S}$ (red) and 45S (green) rDNA loci (scale bar $=10 \mu \mathrm{m})$. (A) tetraploid $H$. syriacus Bali ${ }^{\mathrm{TM}}$ (two $5 \mathrm{~S}$ signals + four 45 signals). (B) hexaploid H. syriacus 'Pink Giant' (three $5 \mathrm{~S}$ signals + six $45 \mathrm{~S}$ signals). (C) oryzalintreated $\left(125 \mu \mathrm{M}\right.$ for $5 \mathrm{~d}$ ), octoploid seedling from H. syriacus Bali ${ }^{\mathrm{TM}}$ (four $5 \mathrm{~S}$ signals + eight $45 \mathrm{~S}$ signals).
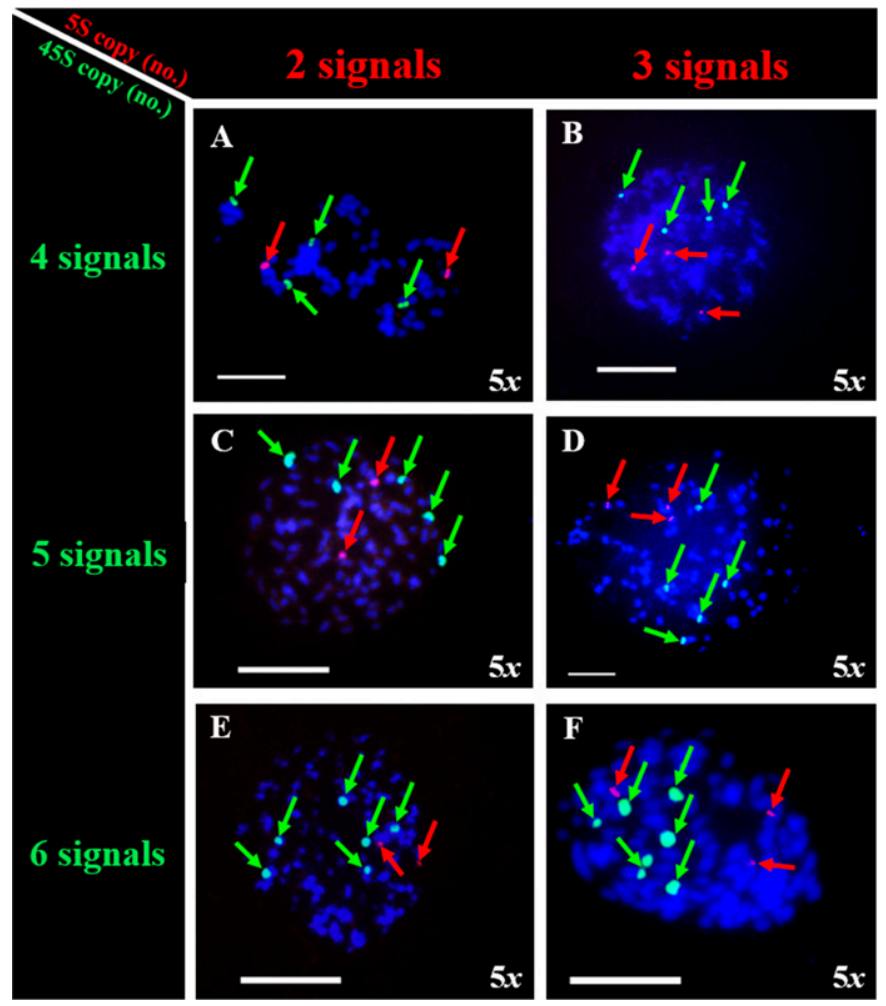

Fig. 5. Fluorescent in situ hybridization (FISH) analysis of metaphase, root tip chromosomes in pentaploid seedlings of Hibiscus syriacus. Chromosomes displaying variation in $5 \mathrm{~S}$ (red) and $45 \mathrm{~S}$ (green) rDNA loci (scale bar = 10 mm). (A) H2013-078-01 'Pink Giant' $\times$ Bali'⿳一 . (B) H2013-131-06 'Pink Giant' $\times$ 'Blushing Bride' $(\mathbf{C})$ H2013-124-19 'Helene' $\times$ 'Pink Giant'. (D) H2013-017-21 'Aphrodite' $\times$ 'Pink Giant'. (E) H2013-085-02 'Pink Giant' $\times$ 'Red Heart'. (F) H2013-049-01 'Diana' × 'Pink Giant'. 
Table 2. Summary of fluorescent in situ hybridization (FISH) analysis in a ploidy series of Hibiscus syriacus.

\begin{tabular}{|c|c|c|c|c|c|}
\hline $\operatorname{Taxa}^{\mathrm{z}}$ & $\begin{array}{c}\text { Accession } \\
\text { no. }^{\mathrm{y}}\end{array}$ & $\begin{array}{l}\text { Holoploid } 2 \mathrm{C} \text { genome } \\
\text { size }[\text { mean } \pm \mathrm{SE}(\mathrm{pg})]^{\mathrm{x}}\end{array}$ & Ploidy $^{\mathrm{w}}$ & $\begin{array}{c}\text { 5S rDNA } \\
\text { signals (no.) }^{\mathrm{v}}\end{array}$ & $\begin{array}{c}45 \mathrm{~S} \text { rDNA } \\
\text { signals (no.) }\end{array}$ \\
\hline Bali'TM $^{\text {TM }}$ & $12-0023$ & $4.61 \pm 0.00$ & $4 x$ & 2 & 4 \\
\hline 'Pink Giant' $\times$ Bali $^{\text {TM }}$ & H2013-078-01 & $5.65^{\mathrm{u}}$ & $5 x$ & 2 & 4 \\
\hline 'Aphrodite' $\times$ 'Pink Giant' & H2013-017-11 & 5.81 & $5 x$ & 2 & 4 \\
\hline 'Helene' $\times$ 'Pink Giant' & H2013-124-19 & 5.89 & $5 x$ & 2 & 5 \\
\hline 'Pink Giant' × 'Red Heart' & H2013-085-02 & 6.07 & $5 x$ & 2 & 6 \\
\hline 'Pink Giant' $\times$ 'Blushing Bride' & H2013-131-06 & 5.97 & $5 x$ & 3 & 4 \\
\hline 'Pink Giant $\times$ 'Aphrodite' & H2013-077-05 & 5.64 & $5 x$ & 3 & 5 \\
\hline 'Blue Bird' × 'Pink Giant' & H2013-044-03 & 5.60 & $5 x$ & 3 & 5 \\
\hline 'Aphrodite' $\times$ 'Pink Giant' & H2013-017-21 & 5.70 & $5 x$ & 3 & 5 \\
\hline 'Helene' $\times$ 'Pink Giant' & H2013-124-03 & 6.31 & $5 x$ & 3 & 6 \\
\hline 'Diana' $\times$ 'Pink Giant' & H2013-049-01 & 5.71 & $5 x$ & 3 & 6 \\
\hline
\end{tabular}

${ }^{\mathrm{z}}$ Taxa represent tetraploid Bali ${ }^{\mathrm{TM}}$, hexaploid 'Pink Giant', an octoploid oryzalin-treated, open-pollinated seedling of Bali ${ }^{\mathrm{TM}}$, and a range of pentaploid progeny recovered from reciprocal crosses with 'Pink Giant'.

${ }^{y}$ Accession number of parent taxa, hybrids, and experimental open-pollinated seedlings.

${ }^{\mathrm{x}}$ Flow cytometry estimates based on leaf samples. Three leaf samples were evaluated for the $4 x, 6 x$, and $8 x$ cytotypes. A single leaf sample was evaluated for the $5 x$ cytotypes.

${ }^{w}$ Ploidy level inferred from genome size estimate.

${ }^{v}$ Number rDNA signals determined using FISH.

${ }^{\mathrm{u}}$ Single leaf samples analyzed by flow cytometry among a large population of pentaploid seedlings to determine putative pentaploids for FISH. rDNA = ribosomal DNA

the tetraploid) to eight (in the octoploid) (Fig. 4). The use of rDNA signals, combined with flow cytometry, proved useful for confirming ploidy levels in $H$. syriacus, a species with numerous small chromosomes. The discovery of only two $5 \mathrm{~S}$ rDNA signals in tetraploids (Fig. 4A) could provide evidence for $H$. syriacus being a diploid, an allotetraploid with disomic segregation (functional diploid), or an ancestral autopolyploid with subsequent elimination of rDNA sites. However, it is unlikely that $H$. syriacus originated from a recent autopolyploid event, as four $5 \mathrm{~S}$ rDNA signals would have been expected.

A recent genome analysis of $H$. syriacus confirms its polyploid status $(2 n=4 x=80)$ after multiple occurrences of whole-genome duplication followed by diploidization after speciation (Kim et al., 2017). In addition, allopolyploidy is common in other species of Hibiscus. Polyploidy has been investigated in Hibiscus section Furcaria with tetraploids, hexaploids, octoploids, and decaploids all exhibiting allopolyploidy (Menzel and Wilson, 1969; Wilson, 1994, 1999). Tetraploids of section Furcaria have been discovered to be allopolyploids including $H$. acetosella (AABB, $2 n=4 x=72$ ) and Hibiscus radiatus (AABB, $2 n=4 x=72$ ) (Satya et al., 2012).

Gossypium, a close relative to Hibiscus in the Malvaceae family, is composed of diploids and allopolyploids. A study of 5S and 45S rDNA revealed that most diploids had two 5S rDNA signals and all allotetraploid species had four 5S rDNA signals (Gan et al., 2013), compared with only two 5S rDNA signals in tetraploid $H$. syriacus. In addition to among-ploidy level variation in rDNA signals, it is possible to have variation within the same ploidy for a species. In a comparative analysis of species in Brassicaceae, species with the same chromosome number were found to have up to a 5 -fold difference in rDNA sites (Hasterok et al., 2006). As only one tetraploid of $H$. syriacus was investigated, the background variability in copy number of tetraploid rDNA signals remains to be discovered.

Low copy numbers of 5S rDNA signals are not unique to $H$. syriacus. Elimination of $5 \mathrm{~S}$ rDNA after polyploidization has been studied in other woody plants such as Rubus (Wang et al., 2015b). Both diploid and tetraploid species of Rubus carried two 5S sites where triploid and octoploid carried only three (Wang et al., 2015b). This phenomenon is common in FISH studies within the Rosaceae as reported for Fragaria (Liu and Davis, 2011), Prunus (Maghuly et al., 2010), and Sanguisorba (Mishima et al., 2002). However, to our knowledge this is the first report of possible 5S rDNA site elimination in Hibiscus.

Elimination of $5 \mathrm{~S}$ rDNA sites in $H$. syriacus could lend evidence to its possible allopolyploid origin. Loss of rDNA has been studied in other allopolyploid taxa such as Gossypium (Wendel et al., 1995), Nicotiana tabacum (Volkov et al., 1999), Tragopogon (Kovarik et al., 2005), Cardamine (Franzke and Mummenhoff, 1999), and Triticum (Baum and Feldman, 2010). Drastic genome reorganization and modification often occur in newly formed allopolyploids (Kotseruba et al., 2003). Genes (rDNA) in these allopolypoids likely undergo the process of concerted evolution and interlocus homogenization (Álvarez and Wendel, 2003). These processes can result in significant changes in rDNA sites, including locus loss as demonstrated in the allotetraploid grass Zingeria trichopoda (Kotseruba et al., 2003). Evolution in allopolyploids often results in copy number and transcription changes in rDNA sites through a process of nucleolar dominance first described by Navashin (1934), where rDNA of one parent can be functionally dominant to the other parent in allopolyploids (Pikaard, 2000). Partial or whole copy loss of rDNA sites in allopolyploids also has occurred from suppressed/inactive nucleolar organizer regions (NORs) that prevent normal replication, leading to stepwise elimination of 
rDNA as observed in cereals (Dvorak, 1990; Gustafson et al., 1988) and N. tabacum (Volkov et al., 1999). In addition, elimination of rDNA can occur rapidly in newly formed allopolyploids. Baum and Feldman (2010) found that in Triticum, elimination of $5 \mathrm{~S}$ rDNA occurred within the first three generations after the formation of allopolyploids.

In the current study, putative pentaploids varied in $5 \mathrm{~S}$ and $45 \mathrm{~S}$ copy number. After interploid hybridization, putative pentaploid seedlings were selected for FISH analysis by flow cytometry of single leaf samples, which produced a range of intermediate genome sizes from 5.60 to $6.31 \mathrm{pg}$. (Table 2). To our knowledge, these selections represent the first FISH analysis on pentaploids from an interploid cross in Hibiscus. Studies on species with natural ploidy series, such as $4 x, 5 x$, and $6 x$ cytotypes of Cenchrus ciliaris (Kharrat-Souissi et al., 2012), have shown proportional increases of rDNA signals associated with each ploidy level. In contrast, a nonrandom distribution of interploid hybrid chromosomes and rDNA sites have been demonstrated in interspecific triploid hybrids of Epidendrum, where all triploids exhibited the same number of $5 \mathrm{~S}$ and $45 \mathrm{~S}$ signals as the diploid parent (Moraes et al., 2013). However, segregation patterns of rDNA signals in $H$. syriacus appeared to be random among the putative pentaploids and signals for each rDNA site ranged between the values of the two parents (Table 2).

From the 12 taxa investigated, all possible parental combinations of rDNA signals were found (Fig. 5). No obvious pattern was observed between parental combinations or genome size estimates and number of rDNA signals (Table 2). From the 12 taxa investigated, two groups of full-sib seedlings were evaluated. From the cross 'Aphrodite' $\times$ 'Pink Giant', three seedlings exhibited two combinations of rDNA signals: $(\mathrm{H} 2013-017-11=$ two $5 \mathrm{~S}+$ four $45 \mathrm{~S})$ and [H2013-017-21, H2013-077-05 (reciprocal) $=$ three $5 \mathrm{~S}+$ five $45 \mathrm{~S}]$. From the cross 'Helene' $\times$ 'Pink Giant', two seedlings exhibited two combinations of rDNA signals: (H2013-124-19 = two 5S + five 45S) and (H2013-124-03 = three $5 \mathrm{~S}+$ four $45 \mathrm{~S})$.

The role of polyploidy on plant morphology and physiology has been studied mostly in natural allopolyploids that have extinct diploid progenitors. The consequences of long spans of evolution following ancient hybridization and whole-genome duplication can obscure the role of polyploidy in variable morphology and physiology (Soltis et al., 2016). The development of vigorous taxa representing an interrelated, wide ploidy series in $H$. syriacus could prove useful in studying the effects of polyploidy on temperate shrubs. Future efforts with this ploidy series include producing clonal replicates of each taxon in the ploidy series and use of mature plants for measurements of morphological, anatomical, and physiological characteristics such as photosynthetic rate, drought tolerance, cold tolerance, pollen diameter, and fertility. Similar research has recently been performed on ploidy series in Brassica (Baker et al., 2017) and $A$. thaliana (Del Pozo and Ramirez-Parra, 2014). However, our ploidy series contains more cytotypes than the few studies on polyploidy and abiotic stress response in woody plants, such as Lonicera japonica (Li et al., 2009) and Prunus salicina (Pustovoitova et al., 1996). Woody, deciduous shrubs with a wide range of ploidy provide a unique opportunity to study winter cold tolerance in relation to ploidy, a topic rarely studied in current literature.

In this study, we identified genome size and ploidy variation in cultivars of $H$. syriacus. We successfully created a ploidy series consisting of $4 x, 5 x, 6 x$, and $8 x$ cytotypes using a combination of interploid hybridization and autopolyploid induction. Among taxa in this ploidy series, we recorded variation in stomatal guard cell length, stomatal density, and copy number of fluorescent rDNA signals. In addition, we found random segregation of rDNA signals in a subset of pentaploid seedlings. This study will provide new opportunities for breeding novel cultivars of $H$. syriacus and the wide ploidy series will provide a foundation for studying physiological differences among ploidy levels in woody plants.

\section{Literature Cited}

Álvarez, I. and J.F. Wendel. 2003. Ribosomal ITS sequences and plant phylogenetic inferences. Mol. Phylogenet. Evol. 29:417-434.

Anamthawat-Jónsson, K. 2003. Preparation of chromosomes from plant leaf meristems for karyotype analysis and in situ hybridization. Methods Cell Sci. 25:91-95.

Baker, R.L., Y. Yarkhunova, K. Vidal, B.E. Ewers, and C. Weinig. 2017. Polyploidy and the relationship between leaf structure and function: Implications for correlated evolution of anatomy, morphology, and physiology in Brassica. BMC Plant Biol. 17:3, doi: 10.1186/s12870-016-0957-3.

Baum, B.R. and M. Feldman. 2010. Elimination of 5S DNA unit classes in newly formed allopolyploids of the genera Aegilops and Triticum. Genome 53:430-438.

Beaulieu, J.M., I.J. Leitch, S. Patel, A. Pendharkar, and C.A. Knight. 2008. Genome size is a strong predictor of cell size and stomatal density in angiosperms. New Phytol. 179:975-986.

Buechler, W.K. 2000. Estimating polyploidy levels using cell size in Salix leaves. Amer. J. Bot. 87:80-81.

Chang, Y.-C., C.-T. Shii, and M.C. Chung. 2009. Variations in ribosomal RNA gene loci in spider lily (Lycoris spp.). J. Amer. Soc. Hort. Sci. 134:567-573.

Chen, G., W.-B. Sun, and H. Sun. 2009. Morphological characteristics of leaf epidermis and size variation of leaf, flower and fruit in different ploidy levels in Buddleja macrostachya (Buddlejaceae). J. Syst. Evol. 47:231-236.

Chen, H., M.-C. Chung, Y.-C. Tsai, F.-J. Wei, J.-S. Hsieh, and Y.-I.C. Hsing. 2015. Distribution of new satellites and simple sequence repeats in annual and perennial Glycine species. Bot. Stud. 56:22.

Chung, M.-C., Y.-I. Lee, Y.-Y. Cheng, Y.-J. Chou, and C.-F. Lu. 2008. Chromosomal polymorphism of ribosomal genes in the genus Oryza. Theor. Appl. Genet. 116:745-753.

Contreras, R. and J.D. Lattier. 2014. Improving a garden classic. Digger 2014(Aug):47-50.

Contreras, R.N., J.M. Ruter, and W.W. Hanna. 2009. An oryzalininduced autoallooctoploid of Hibiscus acetosella Welw. Ex. Hiern. 'Panama Red' (Malvaceae). J. Amer. Soc. Hort. Sci. 134:553-559.

Del Pozo, J.C. and E. Ramirez-Parra. 2014. Deciphering the molecular bases for drought tolerance in Arabidopsis autotetraploids. Plant Cell Environ. 37:2722-2737.

Dvorak, J. 1990. Evolution of multigene families: The ribosomal RNA loci of wheat and related species, p. 83-97. In: A.H.D. Brown, M.T. Clegg, A.L. Kahler, and B.S. Weir (eds.). Plant population genetics, breeding, and genetic resources. Sinauer Assoc., Sunderland, MA.

Eeckhaut, T.G.R., J.M. Van Huylenbroeck, J. De Riek, and E. Van Bockstaele. 2004. Interspecific hybridization between Hibiscus syriacus L. and Hibiscus paramutabilis Bailey. Acta Hort. 630:85-90.

Egolf, D.R. 1970. Hibiscus syriacus 'Diana', a new cultivar. Baileya 17:75-78.

Egolf, D.R. 1981. 'Helene' rose of sharon (althea). HortScience 16: 226-227.

Egolf, D.R. 1986. 'Minerva' rose of sharon (althea). HortScience 21: 1463-1464.

Egolf, D.R. 1988. 'Aphrodite' rose of sharon (althea). HortScience 23:223. Essiett, U.A. and E.S. Iwok. 2014. Floral and leaf anatomy of Hibiscus species. Amer. J. Medical Biol. Res. 2:101-117. 
Fantz, P.R. 1994. Taxonomic problems in cultivated liriopogons. HortTechnology 3:146-150.

Franzke, A. and K. Mummenhoff. 1999. Recent hybrid speciation in Cardamine (Brassicaceae) - Conversion of nuclear ribosomal ITS sequences in statu nascendi. Theor. Appl. Genet. 98:831-834.

Fryxell, P.A. 1988. Malvaceae of Mexico. Syst. Bot. Monogr. 25:1-522. Gan, Y., F. Liu, D. Chen, Q. Wu, Q. Qin, C. Wang, S. Li, X. Zhang, Y. Wang, and K. Wang. 2013. Chromosomal locations of 5S and 45S rDNA in Gossypium genus and its phylogenetic implications revealed by FISH. PLoS One 8:e68207, doi: 10.1371/journal.pone.0068207.

Gerlach, W.L. and J.R. Bedbrook. 1979. Cloning and characterization of ribosomal RNA genes from wheat and barley. Nucleic Acids Res. 7:1869-1885

Gerlach, W.L. and T.A. Dyer. 1980. Sequence organization of the repeated units in the nucleus of wheat which contain $5 \mathrm{~S}$ rRNA genes. Nucleic Acids Res. 8:4851-4865.

Gomes, S.S.L., C.W. Saldanha, C.S. Neves, M. Trevizani, N.R.B. Raposa, M.M. Notini, M.O. Santos, J.M.S. Campos, W.C. Otoni, and L.F. Viccini. 2014. Karyotype, genome size, and in vitro chromosome doubling of Pfaffia glomerata (Spreng.) Pedersen. Plant Cell Tissue Organ Cult. 118:45-56.

Greilhuber, J., J. Doležel, M.A. Lysák, and M.D. Bennett. 2005. The origin, evolution and proposed stabilization of the terms 'genome size' and 'C-value' to describe nuclear DNA contents. Ann. Bot. 95:255-260.

Gustafson, J.P., A.R. Dera, and S. Petrovic. 1988. Expression of modified rye ribosomal RNA genes in wheat. Proc. Natl. Acad. Sci. USA 85:3943-3945.

Hasterok, R., E. Wolny, M. Hosiawa, M. Kowalczyk, S. KulakKsiazczyk, T. Ksiazczyk, W.K. Heneen, and J. Maluszynska. 2006. Comparative analysis of rDNA distribution in chromosomes of various species of Brassicaceae. Ann. Bot. 97:205-216.

Joly, S. and A. Bruneau. 2007. Delimiting species boundaries in Rosa Sect. Cinnamomeae (Rosaceae) in eastern North America. Syst. Bot. 32:819-836.

Kharrat-Souissi, A., S. Siljak-Yakovlev, F. Pustahija, and M. Chaieb. 2012. Physical mapping of 5S and 18S-5.8S-26S RNA gene families in polyploid series of Cenchrus ciliaris Linnaeus, 1771 (Poaceae). Comp. Cytogenet. 6:273-286.

Kim, Y.-M., S. Kim, N. Koo, A.-Y. Shin, S.-I. Yeom, E. Seo, S.-J. Park, W.-H. Kang, M.-S. Kim, J. Park, I. Jang, P.-G. Kim, I. Byeon, M.-S. Kim, J. Choi, G. Ko, J. Hwang, T.-J. Yang, S.-B. Choi, J.M. Lee, K.-B. Lim, J. Lee, I.-Y. Choi, B.-S. Park, S.-Y. Kwon, D. Choi, and R.W. Kim. 2017. Genome analysis of Hibiscus syriacus insights of polyploidization and indeterminate flowering in woody plants. DNA Res. 24:71-80.

Kotseruba, V., D. Gernand, A. Meister, and A. Houben. 2003. Uniparental loss of ribosomal DNA in the allotetraploid grass Zingeria trichopoda $(2 n=8)$. Genome 46:156-163.

Kovarik, A., J.C. Pires, A.R. Leitch, K.Y. Lim, A.M. Sherwood, R. Matyasek, J. Rocca, D.E. Soltis, and P.S. Soltis. 2005. Rapid concerted evolution of nuclear ribosomal DNA in two Tragopogon allopolyploids of recent and recurrent origin. Genetics 169:931-944. Lattier, J.D., H. Chen, and R.N. Contreras. 2017. Improved method of enzyme digestion for root tip cytology. HortScience 52:1029-1032. Lattier, J.D., T.G. Ranney, and N.P. Lynch. 2013. History and cytological reassessment of Rhododendron canadense. J. Amer. Rhododendr. Soc. 67:92-98.

Lee, S.K. and C.S. Kim. 1976. Studies on artificial polyploidy forest trees XIII: Some morphological and physiological characteristics of colchitetraploid Hibiscus syriacus L. J. Korean For. Soc. 32:73-86. Li, W.-D., D.K. Biswas, H. Xu, C.-Q. Xu, X.-Z. Wang, J.-K. Liu, and G.-M. Jiang. 2009. Photosynthetic responses to chromosome doubling in relation to leaf anatomy in Lonicera japonica subjected to water stress. Funct. Plant Biol. 36:783-792.

Li, W.L., G.P. Berlyn, and P.M.S. Ashton. 1996. Polyploids and their structural and physiological characteristics relative to water deficit in Betula papyrifera (Betulaceae). Amer. J. Bot. 83:15-20.
Li, Z. and J.M. Ruter. 2017. Development and evaluation of diploid and polyploid Hibiscus moscheutos. HortScience 52:676-681.

Liu, B. and T.M. Davis. 2011. Conservation and loss of ribosomal RNA gene sites in diploid and polyploid Fragaria (Rosaceae). BMC Plant Biol. 11:157.

Maghuly, F., B. Schmoellorl, E.M. Temsch, and M. Laimer. 2010. Genome size, karyotyping and FISH physical mapping of 45S and 5S genes in two cherry rootstocks: Prunus subhirtella and Prunus incisa $\times$ serrula. J. Biotechnol. 149:88-94.

McGoey, B.V., K. Chau, and T.A. Dickenson. 2014. Stomata size in relation to ploidy level in North American hawthorns (Crataegus, Rosaceae). Madrono 61:177-193.

Menzel, M.Y. and E.D. Wilson. 1969. Genetic relationships in Hibiscus sect. Furcaria. Brittonia 21:91-125.

Mishima, M., N. Ohmido, K. Fukui, and T. Yahara. 2002. Trends in site-number change of rDNA loci during polyploid evolution in Sanguisorba (Rosaceae). Chromosoma 110:550-558.

Moraes, A.P., M. Chinaglia, C. Palma-Silva, and F. Pinheiro. 2013. Interploidy hybridization in sympatric zones: The formation of Epidendrum fulgens $\times$ E. puniceoluteum hybrids (Epidendroideae, Orchidaceae). Ecol. Evol. 3:3824-3837.

Navashin, M. 1934. Chromosomal alterations caused by hybridization and their bearing upon certain general genetic problems. Cytologia 5:169-203.

Ochatt, S.J. 2008. Flow cytometry in plant breeding. Cytometry 73:581-598

Padoan, D., A. Mossad, B. Chiancone, M.A. Germana, and P.S.S.V. Khan. 2013. Ploidy levels in Citrus clementine affects leaf morphology, stomatal density and water content. Theor. Exp. Plant Physiol. 25:283-290.

Pikaard, G.S. 2000. The epigenetics of nucleolar dominance. Trends Genet. 16:495-500.

Prado, E.P., P. Faivre-Rampant, C. Schneider, and M.A. Darmency. 1996. Detection of a variable number of ribosomal DNA loci by fluorescent in situ hybridization in Populus species. Genome 39:1020-1026.

Pustovoitova, T.N., G.V. Eremin, E.G. Rassvetaeva, and V.N. Zholkevich. 1996. Drought resistance, recovery capacity, and phytohormone content in polyploid plum leaves. Russ. J. Plant Physiol. 43:232-235.

Ribeiro, T., A. Barão, W. Viegas, and L. Morais-Cecílio. 2008. Molecular cytogenetics of forest trees. Cytogenet. Genome Res. 120:220-227.

Saltonstall, K., K. Glennon, A. Burnett, R.B. Hunter, and K.L. Hunter. 2007. Comparison of morphological variation indicative of ploidy level in Phragmites australis (Poaceae) from eastern North America. Rhodora 109:415-429.

Satya, P., M. Karan, D. Sarkar, and M.K. Sinha. 2012. Genome synteny and evolution of AABB allotetraploids in Hibiscus section Furcaria revealed by interspecific hybridization, ISSR and SSR markers. Plant Syst. Evol. 298:1257-1270.

Shim, K.K., K.H. Kim, and Y.M. Ha. 1993. Characteristics of triploid cultivars 'Diana' and 'Helene' in Hibiscus syriacus L. J. Korean Soc. Hort. Sci. 34:54-67.

Skovsted, A. 1941. Chromosome numbers in the Malvaceae II. Comptes rendus des traveaux du laboratoire Carlberg. Série Physiologique 23:195-242.

Soltis, D.E., C.J. Visger, D.B. Marchant, and P.S. Soltis. 2016. Polyploidy: Pitfalls and paths to a paradigm. Amer. J. Bot. 103: $1-21$.

Srivastava, A.K. and D. Schlessinger. 1991. Structure and organization of ribosomal DNA. Biochimie 73:631-638.

Van Huylenbroeck, J.M., J. de Riek, and M. De Loose. 2000. Genetic relationships among Hibiscus syriacus, Hibiscus sinosyriacus and Hibiscus paramutabilis revealed by AFLP, morphology and ploidy analysis. Genet. Resources Crop Evol. 47:335-343.

Van Laere, K., A. Dewitte, J. Van Huylenbroeck, and E. Van Bockstaele. 2009. Evidence for the occurrence of unreduced gametes 
in interspecific hybrids of Hibiscus. J. Hort. Sci. Biotechnol. 84:240247.

Van Laere, K., J. Van Huylenbroeck, and E. Van Bockstaele. 2006. Breeding strategies for genetic variability within Hibiscus syriacus. Acta Hort. 714:75-81.

Van Laere, K., J.M. Van Huylenbroeck, and E. Van Bockstaele. 2007. Interspecific hybridization between Hibiscus syriacus, Hibiscus sinosyriacus, and Hibiscus paramutabilis. Euphytica 155:271-283.

Volkov, R.A., N.V. Borisjuk, I.I. Panchuk, D. Schweizer, and V. Hemleben. 1999. Elimination and rearrangement of parental rDNA in the allotetraploid Nicotiana tobacum. Mol. Biol. Evol. 16:311-320. Volkov, R.A., I.I. Panchuk, N.V. Borisjuk, M. Hosiawa-Baranska, J. Maluszynska, and V. Hemleben. 2017. Evolutional dynamics of 45S and 5S ribosomal DNA in ancient allohexaploid Atropa belladonna. BMC Plant Biol. 17:21, doi: 10.1186/s12870-017-0978-6.

Wang, Q., J. Wang, Y. Zhang, Y. Zhang, S. Xu, and Y. Lu. 2015a. The application of fluorescent in situ hybridization in different ploidy levels cross-breeding of lily. PLoS One 10:e0126899, doi: 10.1371/ journal.pone.0126899.
Wang, Y., X. Wang, Q. Chen, L. Zhang, H. Tang, Y. Luo, and Z. Liu. 2015b. Phylogenetic insights into subgenera Idaeobatus and Malachobatus (Rubus, Rosaceae) inferring from ISH analysis. Mol. Cytogenet. 8:11, doi: 10.1186/s13039-015-0114-y.

Wendel, J.F., A. Schnabel, and T. Seelanan. 1995. Bidirectional interlocus concerted evolution following allopolyploid speciation in cotton (Gossypium). Proc. Natl. Acad. Sci. USA 92:280-284.

Wilson, E.D. 1994. The genome biogeography of Hibiscus L. section Furcaria DC. Genet. Resources Crop Evol. 41:13-25.

Wilson, E.D. 1999. Revision of Hibiscus section Furcaria (Malvaceae) in Africa and Asia. Bul. Natl. History Museum London Bot. 29:47-79.

Xiong, Y.-C., F.-M. Li, and T. Zhang. 2006. Performance of wheat crops with different chromosome ploidy: Root-sourced signals, drought tolerance, and yield performance. Planta 224: 710-718.

Zhuang, D.-H. and J.-J. Song. 2005. The characters of pollen grains and stomatal apparatus in Hibiscus L. in relation to ploidy. J. Trop. Subtrop. Bot. 13:49-52. 